\title{
Sustaining peace through school and civil society: mortar, bricks and human agency
}

\author{
Mokubung Nkomo; Everard Weber; Brutus Malada
}

\begin{abstract}
South Africa has been a high-conflict society for nearly 350 years. The first 300 years were characterised by colonial rule with all the attendant conflicts inherent in such polities where dominance over the subjects was achieved by coercive means. This was followed by a more virulent form of racial domination, called apartheid, which characterised the 50 years before the achievement of democracy in 1994. Thus, a legacy of racial inequality is deeply embedded in the institutional structures and psyche of South African society. The principal underlying assumption of this article is that schools are an indispensable part of a consortium of societal agencies that can help bridge the divisions created by apartheid in a systematic and systemic way. The argument is that the critical elements in South Africa that are responsible, thus far, for maintaining relative stability and offer the potential for sustaining human rights, democracy, social cohesion, and therefore, peace are: a progressive constitution; Chapter 9 institutions; derivative educational legislative and policy instruments; an active civil society and human agency informed by a democratic tradition that was bred and nurtured during the anti-apartheid struggle. These vital ingredients constitute the organic mosaic that can further advance peace and stability in the post-conflict South African society.
\end{abstract}

\section{Introduction}

South Africa has been a high-conflict society for nearly 350 years as different white governments implemented one or another form of racial oppression. After the National Party won the all-white elections in 1948 it implemented a system of apartheid that divided the population along racial and ethnic lines, denied black people democratic rights, promoted ethnic division and social and territorial separation among blacks, and especially between whites and blacks, created a segregated, unequal system of education which gave blacks no say in governance and aimed at indoctrination into acceptance of apartheid ideology, and was repressive, intolerant of opposition, and restricted civil liberties. In response, opposition to apartheid flourished after the Second World War and was led by a variety of organisations, the most important of which was the African National Congress (ANC), the present governing party. It took the form of mass campaigns against different laws, demonstrations, strikes, marches and petitions. This post-war resistance was crushed in the 1960s, but resurged more powerfully than before during the mid-1970s and 1980s. It eventually led to a negotiated settlement in the 1990s mainly between the ANC and the National Party, the adoption of a new constitution and, for the first time in the country's history, elections in which everyone could participate, and black majority rule in 1994 . 


\section{openUP}

Today a legacy of racial inequality is deeply embedded in the institutional structures and psyche of South African society. Apartheid wrought great harm with deep roots that will take generations to remove. Bringing normalcy to a structurally and psychically tortured society is the historic challenge facing South Africa in the coming decades. During the 1990s there emerged a mythic vocabulary of the 'rainbow nation', 'unity within diversity', and the 'miracle' of South Africa that became part of the day-to-day vernacular. The broad-based negotiations in the early 1990s produced a constitution that was widely viewed as one of the most progressive in the world, surpassing those of erstwhile claimants of democratic traditions. However, the potential for social eruption is always there concealed beneath a thin veneer unless mechanisms not only for the maintenance of the social compact and peace but also for ensuring sustainability are strengthened.

What can society do to curb the tendency towards anti-human behaviour that can be seen even in societies that once had laudable democratic credentials? Schools can play a vital role in addressing prejudice and intolerance that bring about social conflict. But this is not a role they can play without the accompaniment of other organs of society. Our article will review how, in South Africa, this accompaniment manifests itself in four ways: (a) constitutional and juridical orders; (b) legislative and policy frameworks; (c) statutory bodies designed broadly and specifically to monitor the observance of constitutional imperatives (e.g. the Human Rights Commission,the Gender Commission, the Constitutional Court, the Public Protector's Office, and the National Office of Public Prosecutions); and (d) organs of civil society (e.g. the Centre for Conflict Resolution, the Centre for the Study of Violence and Reconciliation, the National Forum Against Racism, the Institute for Race Relations, Celebrating Difference, the Institute for Democracy in South Africa, the Institute for Security Studies). These are critical mechanisms in South Africa's young democracy. They constitute the mortar and bricks of democracy.

The article also seeks to engage with the concept of peace education as it stands in the existing literature. It is often used in a trans-historical and universal manner, as a desirable state to which all humanity and reasonable people must aspire. This is evident in many of the papers presented at the conference on peace education held in Israel in 2005. Danesh (2006) approvingly cites Harris who lists ten goals for peace education:

to appreciate the richness of the concept of peace; to address fears; to provide information about security systems; to understand violent behavior; to develop intercultural understanding; to provide future orientation; to teach peace as a process; to promote a concept of peace accompanied by social justice, to stimulate a respect for life; and to end violence (p.56).

Danesh draws attention to 'the need for a theoretical framework of peace that will bring together these divergent ...objectives and concepts and would provide the necessary framework for a comprehensive....peace education programme' (p.56). Can there be peace in the face of the most appalling aggression? When the National Party in South Africa during the early 1960s banned all anti-apartheid organisations in the country and jailed black leaders because they opposed white minority rule, the leading political parties 


\section{openUP}

launched the armed struggle. There were no other political alternatives to pursue in the face of the attacks against the oppressed and their organisations. Similar developments occurred in neighbouring countries (Zimbabwe, Mozambique, Namibia, Angola and Guinea Bissau) where white minority regimes and colonial powers maintained power by force. Furthermore, peace education ought to speak far more explicitly to social pathologies and injustice embedded within everyday racial, class and sexual relations, and within supposedly peaceful institutions where structural, domestic and psychological violence are reproduced all the time. The degree to which conflict can be resolved is dependent upon the degree to which policies and actions are free from belligerence, military aggression, and the degree to which social justice is attained. These are problems related more to factors like social, cultural and historical change, than they are to interpersonal relations and fostering feelings of goodwill among students in educational settings.

Inside classrooms and in regard to the curricula subject matter and content, the issues and conflicts of our times ought to be problematised. The literature on critical pedagogy and education for social change and social justice is relevant and appears, by and large, to be ignored by scholars concerned with peace education. Many writers have asked important questions about what is taught and how, such as: who has the power and privilege? How is it exercised? What knowledge and whose world-view are transmitted in schools? Why do groups and nations engage in conflict? How do workers, people of colour, women and other subaltern groups experience life inside and outside schools? What role does education play in reproducing and reinventing inequities and inequalities? (See, for example, Smyth, 1997; Cochran-Smith, 2001.)

Finally, the roles of civil society and human agency are stressed as integral parts of the bricks and mortar that buttress democracy. They must be able to act and critique the state structures and actions, and draw attention to the shortcomings within the existing legal frameworks. This ought to be done from within statutory organizations, independent advocacy groups, research institutions, and outside of government - in trade unions, community, and religious groups. We shall discuss a single example of social activism, the work of the Treatment Action Campaign around HIV/AIDS. Social protest and dissent are as legitimate intellectually, within classrooms in schools and universities, as they are in the streets - otherwise South Africans would presently still be praying for the demise of apartheid.

\section{Policy background and context}

South Africa's new Constitution and Bill of Rights provide the broad contexts for the transformation of the apartheid education system. We wish to highlight three crucial policy initiatives derived from the Constitution that frame the attainment of sustainable peace and school integration in the country, and that seek to give expression to the ideals of the fledgling democracy: the National Education Policy Act (National Department of Education - NDOE, 1996a), the South African Schools Act (NDOE, 1996b), and a focus on the role of values in education. 


\section{openUP}

\section{The National Education Policy Act (NEPA)}

This policy document has been a foundation through which many policies in education were promulgated. In particular it contains additional provisions that reinforce and consolidate the general rights-based approach to education change: it stresses the goal of the 'advancement of democracy, human rights and the peaceful resolution of disputes'; and the attainment of 'equitable education opportunities and the redress of past inequality in education provision, including the promotion of gender equality' (NDOE, 1996a). This statement is particularly significant in the light of the fact that one of the most important characteristics of apartheid schooling was the annual, differential and discriminatory expenditure on education for whites as compared with blacks. The results today are massive inequalities along racial lines. Redressing them is fundamental to the transformation and democratisation of the education system and is a challenge that will take time to overcome.

The law allows for the establishment and continued existence of separatist schools based on language, culture or religion, provided students are not excluded on racial grounds. The latter qualification notwithstanding, the protection of these rights is reminiscent of the key ideological pillar of apartheid schooling. Apartheid education was based on the grand ideology that there was no single South African nation but different racial, ethnic and language groups that had to be separated territorially. Consequently each group (within the overall context of white supremacy) had to develop along its own cultural, socio-economic and political lines and had to have its own separate education bureaucracy, schools, curricula and syllabi. Mother tongue instruction was to be encouraged. The new law is careful in circumscribing language rights: what might be desirable from the perspective of a constitutional democracy is balanced against what is financially viable and, therefore, what the state can afford. A critical question posed by the Act is: is the general rights-based approach to education carried through in other legislation and policies? If not, what are the major areas of tension and contradiction in the official discourses?

\section{South African Schools Act (SASA)}

The South African Schools Act (NDOE, 1996b) seeks to give expression, in theory, to the principles of access, equity, redress, democratic governance and national development. It provides for the establishment of governing bodies with considerable powers at all public schools. School governing bodies (SGBs) consist of the principal and elected representatives of parents, teachers, non-teaching staff, and, in secondary and high schools, students as well. SGBs have the power, inter alia, to: develop the school's mission; determine the school's admissions and language policies; make recommendations on teaching and non-teaching staff appointments; and determine financial management, school fees. They are envisaged as playing a crucial role in fundraising. Their powers do not extend to schools' day-to-day management and to teaching and learning practices, which are regarded as the domain of the principal, senior staff and teachers. The governance model aims at giving schools greater autonomy to manage and control resources, determine the delivery of educational resources, and 


\section{openUP}

extend democracy and local control of education decision-making. It devolves governance to a level where it was effectively denied under apartheid. However, 'the parent is envisioned as one who works with the school and is not, as has been the case in the past, the locus of opposition ...the form of citizenship espoused is largely administrative' (Sayed, 1997, p.361; emphasis in original). The SASA favours consensual politics and decision-making: 'It is assumed that all stakeholders will enthusiastically embrace their moral responsibilities and together build an efficient governing structure' (Grant Lewis et al., 2002, p.8). Carrim (2001) has critiqued the use of the concepts 'roleplayers', 'stakeholders', and 'homogenised communities' contained in the SASA. Communities, he argues, are often divided along racial, ethnic and/or class lines. Such

divisions will in all likelihood influence school politics and school-based conflict in ways that presently still awaits rigorous empirical investigation.

The SASA does seek to further the national goals of democratisation and the rights-based citizenship as enshrined in the new Constitution and the NEPA. The elections of SGB members at schools can be viewed as an extension of, and addition to, the franchise in regard to the national and provincial political structures. Three sets of elections are held throughout South Africa: elections for parliament, provincial government and SGBs. According to the former Minister of Education, Professor Kader Asmal:

They [SGBs] are the third largest democratic process in this country - after the national and municipal elections. As a result of these elections over 200,000 people are elected to sit for a period of more than three years on their local school's governing body. Half of those elected, that is over 100,000, are parents and guardians (quoted in Naidoo, 2004, p.290).

While the Act represents a major and progressive advance over the apartheid governance structures and it currently enjoys far greater political acceptance and legitimacy, it has been realised that some of the schools do not have the capacity to translate some of the policies emanating from this Act into practice and that some of the schools abuse these rights to serve their own political agendas. It is for these reasons that the current Minister of Education (Naledi Pandor) is intending to review the Act.

\section{Values in education}

In February 2000 the then Minister of Education, Kader Asmal, appointed a Values in Education Working Group. The outcome from this commission was a report entitled Values, Education and Democracy (NDOE, 2000). Concomitant to that was another report entitled Freedom and Obligation: a Report on the Moral Regeneration Workshop 1 and II. The Values, Education and Democracy report listed six values that ought to be promoted and encouraged in students: equity and equal rights, tolerance, multilingualism, openness, accountability and social honour. It furthermore recommended pre-service and in-service training for teachers in human rights; the appointment of a working group of social scientists to strengthen, among other things, the teaching of history; promoting debating societies in schools; stronger action against discrimination in schools; and propagating South African national symbols. This report stressed the role of the critical 


\section{openUP}

pedagogy that had its historical origins in not making peace with the apartheid system, but in fighting and struggling against it. The report also highlighted the need for an understanding of human development to challenge racial prejudice, to study the history of all South Africa's people, showing their ties with the history of other parts of the world, and focus on violation of human rights and oppression. The report noted that it has, historically, been expected of Africans to acquire proficiency in the 'white' languages, English and Afrikaans, but that there has been little incentive, pressure or opportunity for white students to master an African language. Thus this process has generally been an assimilation of black culture into the white culture, including the language issue.

Although this report has a lot of progressive ideals, it has also been criticised for being too prescriptive. According to Porteus (2003), prescribing values without a discussion of their meaning and application implies:

a greater consensus than may be possible in context. Delimiting a strong relationship between values and 'patriotism' runs the risk of polarising 'loyalty' ...patriotism implies a loyalty to a nation state, not a set of values or principles. It challenges one to loyalty over and above creative and critical engagement (p.751).

The so-called Freedom and Obligation Report proposes a weekly pledge at school assemblies in which learners should orate as a reassurance of their commitment to the democratic ideals of the country. The pledge, as quoted in Vally (2003, p.712) reads:

I promise to be loyal to my country, South Africa, and to do my best to promote its welfare and the well being of all its citizens and all our various traditions. Let us work for peace, friendship and reconciliation and heal the scars left by past conflicts, and let us build a common destiny together.

Vally writes that the proposed pledge 'is wide open to critique', partly because 'our society remains conflict ridden' (2003, p.712). He nevertheless acknowledges the importance of nation-building and cites Neville Alexander as follows:

[W]e face the real problem in this country that if we do not promote national unity i.e. arrive at a core of common values, practices and national projects (regardless of the class character of the political leadership for the moment), we shall, as in similar cases in recent historical experience in Europe, Africa and Asia, fall apart into warring ethnic groups, each with a more or less separatist agenda (Vally, 2003, p.712).

It should also be noted that while the policies and documents we have referred to here are generally for a good course, the implementation of some of these policies is a quagmire that warrants serious attention. There is no balance between policy formulation and policy implementation due to lack of capacity and political will in other sectors of society. The challenge remains in translating these progressive policies into practice. 


\section{openUP}

\section{School integration initiatives}

One of the major projects undertaken by the Ministry of Education after the inception of democracy has been to deracialise the schools. During the apartheid era schools were organised along racial lines and with the new government seeking to forge a democratic society it was only logical that the old system be abandoned. Broadly, this initiative seeks to offer an opportunity in which learners from every socio-economic background, race, creed, culture, gender and religion can attend together in the same school and the classroom can be exposed to different and common experiences which promote mutual respect. This is an opportunity that is very vital in building a society that is tolerant of its diverse nature, respect for one another, and respect for human rights. It is these values that have inspired the new government and the schooling system to build a foundation starting from its youth. As expected this was not to be achieved without any hiccups. The early days of this process were marked by racial conflicts among parents and learners at schools. The provinces of Western Cape, Gauteng, North West and Limpopo reported a handful of these incidents. However the incident at Vryburg High School in the North West province was an example of racial intolerance at the introduction of school desegregation. This was an incident which many would remember as the 'Babaile saga', named after the student who stabbed a white student in reaction to racial insults. This incident resulted in mutual recriminations from black and white communities. Its prominence in the national media highlighted the challenges that the transformation of South African schools still had to undergo.

While in recent years the admission of black learners is no longer an issue, other schools have adopted subtle ways of denying black learners access to quality education. These include language and school fees (Malada, 2005). With regard to the former, generally Afrikaans-medium schools have used language proficiency as a criterion for admission which results in discrimination against black learners who seldom have a reasonable level of Afrikaans competency to meet the criterion. With the dual-medium schools, where both English and Afrikaans are used as parallel media of instruction, the separation of black and white learners is conspicuous in the classes as black learners attend lessons offered in English and the majority of white learners, especially Afrikaans-speaking, attending the Afrikaans-medium classes. This practice has the effect of perpetuating racial discrimination among the learners. Whether the content that is offered in these two streams is of the same quality is yet another question that requires further investigation.

The South African history of 'separate development' - apartheid - has also given birth to serious economic inequalities with the majority of the black people located in the 'second economy' while the 'first economy' is white-dominated. The latter is characterised by high income levels and cultural capital that advantages white learners. Whites in general can afford the high school fees while blacks in most cases cannot. This then makes the high school fees a discriminatory device. It remains to be seen whether the recent initiative from the Ministry of Education on 'non-fee schools' and 'exemption of fees' for those who cannot afford fees will help redress these discriminatory practices. 


\section{openUP}

The education legislative and policy texts we have discussed in this section have to be viewed in conjunction with the role of several institutions in civil society that seek to ensure peace. Some of these have been created in terms of Chapter 9 of the Constitution, while others operate independently of the formal legislative provisions. In the following discussion, we analyse the role of civil society structures in the efforts to build and sustain a peaceful and democratic society in South Africa.

\section{The role of civil society structures in sustaining peace}

The architects of the apartheid system used civic structures and the schooling system as state apparatuses through which apartheid was promoted and maintained. Ironically, many of these structures became involved in the anti-apartheid struggle. They also ran numerous community education programmes, with some concentrating on conflict resolution with elements of peace education. In the following section we present exemplars of programmes and initiatives in civil society structures with the same aim of promoting a society that has respect for human rights, the culture of democracy and sustainable peace.

Given the history and the legacy of apartheid, the current government and the civil society/community informed by the mission and vision of a democratic country, it became necessary to establish institutions that would monitor and support these principles and values. In fact, the issue of sustained peace and democracy in South Africa is not a responsibility of the government alone. There are various structures of government, non-governmental organisations (NGOs), community-based organisations (CBOs), and private sector organisations that are involved in the peace development process. The basic role of these institutions is to monitor, support and enhance constitutional democracy in the country and this is done through what can be referred to as peace education programmes.

Among these structures are the Truth and Reconciliation Commission, The Human Rights Commission and many others. In this article we elaborate on the role these structures and other civil organisations play in building, maintaining and sustaining a society imbued by the values of democracy, human rights and peace.

\section{Constitutional structures}

Through the negotiation processes on the eve of democracy in South Africa, one of the major challenges of the Congress for a Democratic South Africa commission $(\text { CODESA })^{1}$ was to lay a foundation to 'deal with the past in a way that would break the cycles of violence, bring about social cohesion, and restore peace' (Gobodo-Madikizela, 2003, p.148). It was this concern that gave birth to the Truth and Reconciliation Commission.

The Truth and Reconciliation Commission, commonly known as the TRC, played a critical role in establishing peace, and building a foundation for non-revenge and forgiveness among South Africans, both victims of the system and perpetrators. It 


\section{openUP}

presented an opportunity to forge a peaceful society by calling upon both the culprits and those who lost friends, relatives and loved ones as a result of the actions of apartheid rule to testify and seek amnesty so as to build a united and peaceful South Africa.

While we cannot downplay the role of the TRC in installing peace and reconciliation in South Africa, it should be noted that the efforts of the TRC are not valued equally by all people. Often the differences have racial overtones. One of the major criticisms of the TRC process stems from its failure to give amnesty to some former liberation combatants. The other relates to the apartheid offenders who were not subpoenaed to the TRC proceedings or cases where the TRC failed to find any evidence linking them to such offences, while it is common knowledge that in their capacities in strategic positions of power, they had all the power to stop or allow the atrocities to happen.

Despite the efforts to destabilise and instigate racial tensions by groups such as the Boeremag, ${ }^{2}$ it is without doubt that the TRC made a meaningful contribution to what South Africa is today. The TRC was an important tool in the period of transition. The challenge has been to ensure that these efforts are sustained even after the 'honeymoon' was over. Thus, for South Africa, it became important to have institutions that would monitor and enhance constitutional democracy throughout. One outstanding institution in efforts to build a peaceful society is the South African Human Rights Commission (SAHRC). In particular the SAHRC was established to ensure that it promotes, protects and inculcates the culture and respect for human rights and it achieves this by raising awareness through workshops, seminars and educational training workshops.

It is worth noting that in the past few years of school curriculum reform in South Africa, the SAHRC has actively participated in these processes, ensuring that the curriculum addresses pertinent issues of democratic values, human rights and social justice. The Revised National Curriculum Statement, a national curriculum policy document, has embraced these values more explicitly. The schooling system has become one of the immediate beneficiaries of the SAHRC racial integration and human rights programmes. For instance, in 1999, the SAHRC commissioned a study on Racism, Racial Integration and Desegregation in South African Public Schools. The findings of this study underscored the need for more input on racial integration and awareness programmes in schools. Following the study a conference on racial integration in schools was convened. Furthermore, a consultative forum on racism in education, comprising various stakeholders, was established. All these efforts are designed to stabilise and deepen South African society's understanding of democracy and peace and create a conflict-free society.

It would seem from the above that the work of the SAHRC has been generally commendable. However, the success of these programmes hinges on the support that the institution receives from its custodians. While the above achievements should be hailed, the nature of support that the government has offered to these institutions has been a focal point of criticism. For instance, the allocated budget to the SAHRC has not been sufficient to effectively execute its statutory mandate. 


\section{openUP}

The other general concern with most of South African institutions, especially government institutions, is their failure to effectively deliver services. This stems mainly from lack of capacity of the organisations to carry out their designated activities. As a result, many state departments in recent years have witnessed huge sums of money returning to the treasury simply because the organisations were unable to spend their allocated budgets.

Other than constitutional structures like the SAHRC, there are many other institutes and organisations that are involved in various aspects of peace-building activities. Some work independently while others work in collaboration. We refer to these institutes and organisations collectively as 'civil society structures'.

\section{Civil society structures}

There are many non-governmental organisations in South Africa but few of them work in the area of peace education. Examples of those working in the area of peace education include the following:

a. The Center for Conflict Resolution, located at the University of Cape Town, offers mediation and capacity-building to settle conflicts and to promote public awareness of the value and practice of constructive conflict resolution (www.ccr.uct.ac.za);

b. The Center for the Study of Violence and Reconciliation also offers training programmes to provide insight into the causes and consequences of crime, violence and information on how participants could respond to those problems (www.csvr.org.za);

c. The Institute for Democracy in South Africa (Idasa) is a research organisation focusing on research to monitor and deepen democracy within civil society (www.idasa.org.za). Idasa is one of the institutions that helped to facilitate the negotiated settlement in South Africa prior to the 1994 elections.

d. The Institute for Security Studies is also a research organisation, focusing on issues of conflict resolution and peacekeeping in southern Africa (www.iss.org.za).

What is common to these organisations is that what they offer could be summarised as educational interventions that are aimed at building a culture of human rights and democracy, a culture of non-violence, tolerance and respect, and the elimination of prejudice and discrimination in society. Although these commonalities exist, they seek to achieve this common aim by different means, targeting different groups such as the youth, military, political organisations and civil society in general. While some are academic programmes in which participants are offered certificates, e.g. the Center for Conflict Resolution at the University of Cape Town, others are purely conducted on $\mathrm{ad}$ hoc bases depending on the need.

In analysing some of these programmes it becomes clear that the initiatives from civil society structures are characterised by two approaches: positive peace education and negative peace education. The negative peace education approach is reactive and can be 


\section{openUP}

understood as an approach that tries to put out fires in that it helps parties in dispute to resolve their conflict. Some of the structures use a combination of positive and negative, while others use either one of the two approaches. It is, however, our view that a country in transition like South Africa would find a more consolidated approach which combines the two to be very useful in the efforts to sustain peace through education. We argue that in post-conflict societies we require multiple strategies and interventions at different levels to stabilise tensions as much as we need awareness programmes.

However, it is also important to note that both government and initiatives from the civil society have their own pitfalls. Some of these programmes are not able to achieve as much as they could due to lack of adequate support and funding. In other instances we have found serious conflict of interest between the government and the organisations, ending in litigation. For example, the SAHRC has on several occasions taken the government to court over a number of issues including land removals. Another example is illustrated by complaints that, although the government professes to support the SAHRC, it does not fund it adequately to ensure the effective implementation of its mandate.

Although these programmes from the civil structures and NGOs appear to be for a good cause, there are no adequate supports and effective implementation by the civil society itself. Some of these problems emanate from the fact that their programmes are not reaching to the grassroots and, as a result, civil society is not making use of these programmes or benefiting from them, as they are unaware of their existence (Calland \& Graham, 2005). This largely affects the rural and the poor since the means of communication used are not at their immediate disposal.

One area in which great confusion has been sown is government policy on HIV/AIDS and the distribution of antiretroviral medication. It provides a classic example of, on the one hand, policy bombast and, on the other, execution aversion. Civil society organisations have been active in challenging the government on its lack of commitment and betrayal of policy intentions. A snapshot of the social activism in civil society on the global march for medical treatment on 9 July 2000 is illustrated by the following account.

In May 1998, Ms Gugu Dlamini was stoned to death in Durban for revealing that she was HIV positive. A few days later 5000 people, many wearing 'HIV Positive' T-shirts, gathered at the Durban city hall to demand equitable access to HIV/AIDS treatment. The excited group of nuns, drag queens, sangomas, doctors, communists, teenage punks on skate boards, Pan-Africanists, gay activists, unionists and nurses had come from all over Durban and the world to join the Global March for Access to HIV/AIDS treatment. Gugu Dlamini had been vindicated and the demand for equitable access to HIV/AIDS treatment had been turned into the single biggest issue confronting the 13th International AIDS Conference. Previous conferences had focused on prevention but now treatment - and equitable access to treatment - were topping the agenda (Pithouse, 2000, n.p.).

The 16th International AIDS Conference, held in August 2006 in Toronto, Canada, saw vigorous criticism of the South African government's failure to roll out a wholesome 


\section{openUP}

distribution of antiretrovirals. A public statement issued by government regarding the establishment of a body to review its policy appears to be a response to protests by civil society organisations.

\section{Human agency}

Bricks and mortar are undoubtedly crucial ingredients in the construction of a dwelling. The dwelling, however, does not become a 'home' until it is graced by human occupancy bringing with it a repertoire of styles, motivations, preferences and values. The character of the home then derives from the character and personality of its occupants. Societal character or personality is informed by particular histories, experiences and the force of the leading agents for transformation at particular historical moments.

The present sociopolitical condition of South Africa derives from a set of circumstances ranging from a political culture and tradition that, by and large, reflect the ascendancy and prominence of an ideology of relative tolerance and accommodation in the last 50odd years. It is the steadfast adherence to this culture that, to a large measure, explains the 'miracle' that has enjoyed relative stability during the transition phase. It is rather remarkable - certainly telling - that South Africa has the largest number of Nobel Peace Prize recipients in the world (Albert Luthuli, Desmond Tutu, Nelson Mandela and F. W. de Klerk). In addition, there is a pantheon of activists across a broad spectrum of organs of civil society who emerged out of the mid-1980s United Democratic Front campaign informed by the 1950 s political culture, ideology and practice (i.e. 'South Africa belongs to all' and 'nonracialism'). It is reasonable to suppose that this amalgam of factors largely explains the present condition of relative peace and stability in South Africa. But complacency must not be allowed to prevail as it may be fraught with explosive subterranean currents that could potentially undermine a nascent and fragile democracy. Robust, energetic and sustainable effort is essential to preserve the erstwhile democratic ideology practised during the campaign for democracy; to ensure the entrenchment of a peace ethos; and deepen a culture of human rights.

\section{Conclusion}

We have surveyed the bricks and mortar of the new democracy and have argued that, complemented by human agency, they contextualise and underpin contemporary education reform in South Africa. We have analysed the democratic constitutional and policy frameworks and the institutions of civil society that can, at the macro level, sustain peace education and specific programmes of action. The history of South Africa teaches the value of opposition and resistance in the face of oppression, and in the pursuit of peace, justice and human rights. 'No justice, no peace' was one of the popular slogans of the civil rights movement in the United States and its spirit prevailed during the mass anti-apartheid marches, strikes and campaigns of recent decades in South Africa.

The legacy of the past continues to provide the basis for tension and conflict in civil society, and it will be with us for a long time to come. The role of education is to problematise the contentious issues of the day, and to provide an intellectual and 


\section{openUP}

pedagogical space for open-ended discussion and debate. We believe that the key tenets of outcomes-based education, the provisions of the South African Qualifications Authority Act (NDOE, 1995) and the principles of the Values in Education initiative, advocate these objectives. In this respect they are consistent with the goals of the antiapartheid People's Education Movement of the 1980s. Put another way, in the same way that the current government policies can and have been critiqued, and in the same way that there exist both officially and in civil society independent organs for monitoring democracy and human rights, education curricula, textbooks and pedagogies must address the social concerns and current events of our society. This means, above all, creating the ethos and enabling environment in which diversity in terms of race, gender, class, ethnicity and thought - most especially critical thought - can flourish. Historically, suppressing the 'other', or pretending the 'other' does not exist, created a peace-less environment that created centuries of suffering and conflict in the country.

We believe that peace, democracy and human rights have a wider context than has hitherto been acknowledged in education reform in South Africa and that such a perspective ought more consciously to inform work in our classrooms in future. This, too, sets the agenda for future research and analysis.

\section{Notes}

1. This was a commission established for the negotiation process between the liberation movements and the apartheid ruling party (National Party) in preparation for a democratic South Africa.

2. A group of disgruntled white Afrikaners who are refusing to recognise South Africa as a democratic state. They demanded the establishment of a Volkstaat, a land/province to be exclusively for white Afrikaners only, without success. As a result they resorted to crime and violence which they are now well-known for. Some were arrested in 2005 and are now appearing in courts on treason charges.

\section{References}

Calland, R. and Graham, P. (2005). Democracy in the time of Mbeki. IDASA Publishing, Cape Town

Carrim, N. (Jansen, J. D. and Sayed, Y. eds.) (2001). Democratic participation, decentralisation and educational reform. Implementing education policies: the South African experience pp. 98-109. University of Cape Town Press, Cape Town

Cochran-Smith, M. (Hargreaves, A., Lieberman, A., Fullan, M. and Hopkins, D. eds.) (2001). Teaching for social change: towards a grounded theory of teacher education. International handbook of educational change Kluwer, Dordrecht

Danesh, H. B. (2006). Towards an integrative theory of peace education. Journal of Peace Education 3:(1), pp. 55-78. 


\section{openUP}

Gobodo-Madikizela, P. (2003). A human being died that night: a story of forgiveness. David Philip, Cape Town

Lewis, S. Grant, Naidoo, J. and Weber, E. (2002). The participation paradox: South Africa's school governance policy. Unpublished paper

Malada, B. (2005). School integration must be a total system: school integration is deeper than the sharing of schoolyard. City Press, p.18.

Naidoo, J. (2004). Educational decentralization and school governance: from policy to practice. D.Ed. thesis, Harvard Graduate School of Education

National Department of Education (NDOE). (1995). South African Qualifications Authority Act. Government Printer, Pretoria (No.58 of 1995)

National Department of Education (NDOE). (1996a). National Education Policy Act Government Press, Pretoria (No. 697 of 1996)

National Department of Education (NDOE). (1996b). South African Schools Act Government Press, Pretoria (No. 84 of 1996)

National Department of Education (NDOE). (2000). Values, education and democracy. Report of the Working Group on Values in Education. Government Printer, Pretoria.

Pithouse, R. (2000). Global march for treatment access. Available online at: www.tac.org.za/Documents/Other/march (accessed December 2006)

Porteus, K. (Chisholm, L., Motala, S. and Vally, S. eds.) (2003). The personal and the global: grinding gears? Reconsidering efficiency debates in general election. South African education policy review, 1993-2000 pp.745-800. Heinemann, Sandown

Sayed, Y. (1997). Understanding educational decentralisation in post-apartheid South Africa. Journal of Negro Education 66:(4), pp. 354-365

Smyth, J. (Biddle, B. J., Good, T. L. and Goodson, I. F. eds.). (1997). Teaching and social policy: images of teaching for democratic change. International handbook of teachers and teaching. Kluwer, Dordrecht

Vally, S. (Chisholm, L., Motala, S. and Vally, S. eds.). (2003). Reassessing policy and reviewing implementation: a maligned or misaligned system? South African education policy review, 1993-2000. pp. 697-743. Heinemann, Sandown 